\title{
Travel Writing in Children and Adolescent's Literature in Iran
}

\author{
Maryam Jalali (Corresponding author) \\ Department of Persian Language and Literature, Shahid Beheshti University, Tehran, Iran \\ E-mail: Jalali_1387@yahoo.com \\ Narges Bagheri \\ Department of Persian Language and Literature, Vali-e-Asr University of Rafsanjan, Rafsanjan, Iran \\ E-mail: N.bagheri@vru.ac.ir \\ Masoomeh Mahmoodi \\ School of Allied medical sciences, Mazandaran University of Medical sciences, Sari, Iran \\ E-mail: Masoomehmahmoodi@yahoo.com
}

Doi:10.7575/aiac.alls.v.7n.2p.1

URL: http://dx.doi.org/10.7575/aiac.alls.v.7n.2p.1
Received: 20/10/2015

Accepted: 23/12/2015

\begin{abstract}
Today children's literature and its place have attracted in the collection of literature, according to many writers the world. Making fun of the text by writer is best way to communicate with the Children and Adolescents. Travel writing is considered as an interdisciplinary literature combined by literature, history, geography and sociology. It is written both in verse and prose. Writing Travel writing is well- established in adults' literature. Although several Travels writing have been written in adults' literature domain, it is not well-established in children and adolescents literature, so the experts and the writers of children and adolescents books should pay more attention to this issue. Children's Travels writing don't differ from the adults' one in first definition. However, there are some differences from structure and theme towards their special addressees with the adults' ones.
\end{abstract}

Keywords: children, literature, Travel writing, Iran

\section{Introduction}

Communication plays a leading role in today's world. High technology is ubiquitous such as internet, satellite and all types of mass media, traveling and travel writing serves as an interesting and effective means of communication in human communities and different customs.

Travel writing in Iran has been taken into consideration since Safavid era and in addition to the books written by the kings like Naser al-Din Shah Qajar and Mozaffar ad-Din Shah Qajar, his son, there are travelogues written by some of their courtier and political figures including the travelogue of Nezam al-Saltaneh (chief adjutant of Fath-Ali Shah Qajar) which is about his travel to Austria, France and Britain between 1875 and 1876, the travelogue of Amin al-Dawla Mirza Ali Khan (1844-1904), the chancellor of Mozaffar ad-Din Shah Qajar which is about his travel to Mecca, and Makhaza al-Vaghaye the travelogue of Farrokh Khan Amin al-Dawla (1814-1877), Iran's ambassador in Europe, and etc. Also, from European tourists who have traveled to Iran since the 17th century and reflected social and political conditions of Iran, traditions of Iranian people and the court state in Safavid and Qajar eras in their literature, there have been remained many travelogues most of which translated into Persian. Some of the European tourists tried to illustrate cities, buildings and figures during their visits; some of them even employed an illustrator when heading to the Orient to have them draw the pictures that they want.

In fact, travelogues are well-designed screens of different scenes of social life of countries which are included in their contents. However, reflecting the conditions and the pictures of the societies in travelogues are depending on the author's taste, rather than a specific formula. Therefore, these contents are very different in the pictures in which Iranian society has been reflected by the European tourists (Panahi, 2009: 47)

From long ago, our ancestors have been enthusiastic in travel Writing. They wrote whatever they had heard and seen in form of travel writing of their travels. The Travel writing of Naser Khosrow is known as the most famous one written in 5A.D.

Travel writing in Iran is common for the adults, but for the children it has been popular since 1905, though it is in fact one of the few genres in the children' literature. It seems that little attention has been paid to this genre in the Iranian 
children's literature, but regarding the proper ideas which is being considered for this literary genre, it is worth to develop it.

"Literature is the mirror which is reflects the mind, inner feelings and the known and unknown needs of humans. Thus children as members of society have right to choose their own literature. Books for children to learn and to read as their own choice are available in a various categories such as history, science, biography, and fiction with different beginning reader levels".( Jalali,2015: 1)

Travels writing are providing for children lots of historical, cultural, social and geographical information. These types of texts are valuable from both literary and historical points of views for children and adolescents. "Some travels writing present the very true history of a nation disgracing official history writers of a country" (Karachi,2002: 23). Travel writing is defined as explaining whatever seen, heard, remembered and happened during a journey for a passenger and it contains lots of information. (Safi,2003: 43). While travel writing for children, some important elements should be considered like children's mental specifications, not enough experience, low knowledge and limited vocabulary range.

Travel writing for children in Iran is a kind of reporting in which the author describes his observations from the situations of cities or countries and some information about historical buildings, mosques, libraries, bazaars, famous figures, national or religious traditions of the people, geographical location, population, weather, local languages and regions that he has visited.

The current research analyzes some travels writing for children from $1950_{2}$ to the end of 2010 .

\section{Types of Children and adolescents' Literature}

There are different between literature for children and adolescents, for example it is in the genres, models and styles. In teen's literature are seen kinds of genres as like: Epic, lyrical, spiritual, moral, and in the form of it, there are short short stories, short stories and novels and etc. in models. Moreover in style of writing there are the real story, fiction and fantasy. In fact, the boundaries are determined between children and adolescent's literature by their needs for having special text. All of them are with social content at a higher level and seeing teen needs as exemplary that we cannot find them completely in children's literature for young children and teen is so important because he or she is audience.

At present, I have to say, children travelogues are divided into two categories based on the form: Written and unwritten. In the written from, travelogue is recorded by writing, but the unwritten form of travelogue which is created by children and youths in the modern era consists of different forms such as various pictures and photos from the visited sights and places, videos or audio files recorded during the travel and also travel illustrations. This form of travelogue can also be presented as computer games.

There are a few views about travel writing. Some critics consider travel writing as nonfiction and they divided nonfiction to:"1-scientific books 2-books related to the society and environment (social science) 3- books about inventions and explorations 4-books about activities and entertainments 5- books on art 6-biograpgy and autobiography"(Hejazi,2004:49). Soraya Ghezelayagh writes about documents in children and adolescents that" the domain of documents for children and adolescents embraces all fields of science, theology, arts and human skills and they are classified as: scientific books (pure and applied); social science books( history, Travel writing, customs, social issues and, etc.); humanity( religion and philosophy, opinions, evolution direction and, etc); biography(artists, athletes, intellectuals, scientists, poets, writers, politicians); game and entertainments( sport, thought games, buildings and, etc) and books about ."(Ghezelayagh, 2006: 232). Children and adolescents' Literature is generally divided into three categories: Prose; Poem; Dramatic text. In the continue prose and poem is divided to two branches: fiction and nonfiction (Jalali, 2015:78).

However, I'm going to pay the travel writing as the genre that it is writing for both the audience (children and teen) in Iran. So I need a more general classification. The basis of my division, it is the "literature" in specific usage in the texts. The travel writing can be prose or verse text in form of the fiction and nonfiction.

Mohammad Bagher Hoshiar, Jabbar Baghchehban, Ebrahim BaniAhmad and Abbas Yamini Sharif are the pioneers creating noon-story literature. They paid attention to make children aware through informative texts and they were also concerned about lack of books for children. Furthermore, they used story or semi-story structure to make informative texts more absorbing. On ship on Caspian Lake is categorized in this type published in Danesh amuz magazine in 1953 in which Mohammad Bagher Hoshiar as used a conversation pattern between a father and his son trying to answer some of the children's questions about natural phenomena. Nazi's travel to sky is a semi-story published in Naghmeye Kudak magazine in 1959. It was written for pre-school and primary students. It provides the readers with information about moon and stars.

After 1960s late Nader Ebrahim published the Safarhaye duro deraze hami VA kami dar vatan [the long journey of Hami and Kami across the country] inside the Country in 1977. It psychologically illustrates the relationship between elderlies and children. Travel writing has been publishing in a better quality and quantity since 2000. Mohammad Kazem Mazinai has written the lost sea and panj ruz dar nimruz[ Five days in mid- day]in form of travel writing in 1990. He wrote these books in his travel to Sistan and Baluchistan province and described the specifications of this land and the native people. Part of the itinerary is for children and some part is for adolescents. 


\section{Different Travelogues written for Iranian children}

Travelogues written for Iranian children are either created by adults. In Iranian adult travelogues, there is another genre known as allegorical travelogue. This kind of travelogue has not been applied in Iranian children's literature. Moreover there are certain travelogues in Iran being written by children and they are mostly being published as reader's essays in youth and children's publications. These travelogues have been rarely published as books. In this article I will not mention them.

Real Travelogue: These travelogues are describing travels that happened in real and the author writes the descriptions of what he saw, what he heard and what occurred to him during his travel.

Abbas Yamini Sharif was the one who published the first Travel writing book in 1966 called Donyagardie jamshido Mahshid [Jamshid and Mahshid traveling all around the world]. The writer tries to make children familiar with the life and culture of people from various countries in form of story by two characters called Jamshid and Mahshid. The narrator use to describe the climatic and geographical situation of every new country. Then, he explains the specifications of face, clothing, home, transportation, gastronomy, farming, handicrafts and rituals of every land. Next, he retells stories quoted by an elderly guesting Tiran and children. The book language is simple and matched with the addressee's knowledge and capability". (Mohammadi \& Gaini, 2001: 860). Many books have been released to make children familiar with different cities and countries as well as entertaining, historical and religious places such as Zire navdane tala[under the golden downpipe]written by Najaf Ali Mohajer describing the writer's traveling to Karbala in his childhood. Ramak Nik Talab(2005), Bita shajareh (2008) and Fariba Bashiri(2007) have also written the series of the Safarhaye Dara VA Sarah dar Iran [Travels of Sarah and Dara across Iran] in several volumes. Sarah and Dara are children's two favorite characters traveling all across Iran and making children familiar with the customs, traditions and people of cities of Iran. One of the most favorite travels writing written for children and has been the text book of the third grade of primary school is The story of Mr.Hashemy's Family'.' It is in schools books for 20 years and written by Gholam Ali Haddad Adel. They travel for a job mission. Mr.Hashemy's family started their travel from Kazerun. They pass through several cities to reach Neyshabur. Children get familiar with the religious, cultural, historical and geographical specifications of different cities of Iran.

Fictional Travelogue: In these kinds of travelogues, the author does not travel in real but describes his views and thoughts in a form of travelogue. These travelogues are categorized as follows: Philosophical Travelogues; EthicalReligious Travelogues, Social Travelogues, and Science-Fiction Travelogues.

Science-fiction travelogues in Iran are mostly written for youths. The definition of science-fiction in the Oxford English Dictionary is as follows: "Fiction based on imagined future scientific discoveries, major environmental or social changes, etc., freq. involving space or time travel or life on other planets" (See: Adams, 2004:170).

Iranian travelogues written for the youths in science-fiction genre are as follows: Bazgasht be Zamin pas az Zohour [Return to the Earth after the Manifestation](Rahimi Bandar Abadi ،2002); Raz-e Ghal'eye Aflak [The Secret of the Aflak Castle] (Navaei Lavasani, 2009); Sari'tar az Nour [Faster than the Light] (Hoseinein ،2010); Mosafer-e Sayareye Urapus[The Urapus Planet's Passenger ] (Najafi ،2001); Majmou'e Dastan'haye Elmi Takhayoli [Science-Fiction Stories](Azimi ،2003); Mantaghe'ye Sefr-e Fazaei [Zero Space Region] (Navaei Lavasani, 2009).

For example, in Raz-e Ghal'eye Aflak [The Secret of Planetarium Castle] (Navaei Lavasani, 2009), a girl named Niloufar finds an strange metal object and then goes to explore the Falak-ol-Aflak Castle with his brother and his uncle Mahmoud. But they suddenly pass out and then wake up and find themselves in another planet. There, together with Piro (their alien friend) they help the Zaxis (alien creatures) to become free from the Airos' domination. Protagonists of the story unconsciously go to another planet.

One of the story characters is usually introduced as hero and the story events are about him. This hero is sometimes revolved in some stories, while he is fixed and stable in some others. Since children can't travel alone and they should travel by family, children travel with their family and usually with their sister or brother. They may travel for job mission or entertainment. Among the works studied so far, the heroes of eight works are the sisters and brothers travelling with family or alone. Main characters are not usually developing characters and they remain unchanged. However, they can be affected by the culture, customs of the nations they visit and learn new training, historical and social. Travels writing contain valuable information on various cultural, historical, social and natural subjects. Each can be applied in children Travels writing. Time and place are considered as two important factors in travel report. Time sequence is very essential in Travels writing taking longer time. In this type, travel starts from a specific time or point and finishes in another time or place. The reader goes step by step with the reporter or writer.

The author of Raz-e Ghal'eye Aflak has applied the objective manifestations of traveling to the other planets and being familiar with exotic aliens to give it a science fiction form. Being a travelogue, this story helped that the other story elements to be highlighted. The distinguishing aspect of science fiction elements among other story elements is their function in such stories; for example, in science fiction, the scene-setting element describes unbelievable scenes. Their characterizations make them special due to the presence of aliens and non-human creatures. The plot of science fictions is made of successive complications, suspense and possible verisimilitude versus science. In this kind of stories, the fact there are science or travelogue themes helps it a lot in being fictional. Because of unknown situations in these stories, the author needs a point of view through which he can dominate all aspects of the story and describe ambiguous situations. 


\section{Objectives of travel writing for Children and adolescents}

Realistic travelogues for youths and children in Iran have been mostly written about religious places. Travelogues that are served to entertain this age group and to improve their mental experiences are mostly fictional. Recently, some rewrites of the ancient travelogues such as Travelogue of Naser Khosrow have been done for youths and children in Iran. Safarnameye Naser Khosrow [Travelogue of Naser Khosrow] rewritten by Naghmeh Alibeikzadeh, Safarnameye Naser Khosrow be Zabane Emrouzi [Travelogue of Naser Khosrow in Modern Language] (2002) rewritten by Hosein Amouzgar and Mosafere Gheble [The Passenger of Qibla] (2011) rewritten by Alireza Kamari are some instances of these travelogues:

- Introducing children to the concept of travel;

- Defining the travel as a healthy amusing action;

- Introducing children to the other geographical locations and cultures;

- Strengthen children's minds in observing and recording the details;

- Fostering children's imagination;

- Allowing children enjoy by fantasying impossible travel experiences;

- Contributing to the development of children's communication skills.

I have collected the most itineraries and themes brought it. These themes confirm the Objectives of travel writing for children that I mentioned them. The following tables show the story's themes:

\begin{tabular}{|c|c|}
\hline Children's Stories & Theme and Genre \\
\hline $\begin{array}{l}\text { Safar be Shahre Soleiman (Travel to the } \\
\text { Solomon's City) }\end{array}$ & Cultural Fiction \\
\hline $\begin{array}{l}\text { Safar-e Saltanati be Behesht [Royal Travel to } \\
\text { Heaven] }\end{array}$ & Educational Fiction \\
\hline Safar-e Barf [Tavel of Snow] & Educational Fiction \\
\hline Aghaz-e Safar [The beginning of Travel] & Realistic Individual Experience \\
\hline Shahr'e Badkonak'ha [The City of Balloons] & Cultural Realism \\
\hline Az Ghatar ta Kashti [From Train to the Ship] & Individual Experience \\
\hline Safar-e Daryaei [Traveling by Sea] & Individual Experience \\
\hline $\begin{array}{l}\text { Safar'haye Atal O Matal [Travels of Atal \& } \\
\text { Matal] }\end{array}$ & Educational Fiction \\
\hline Se Hamsafar [Three Traveling Companions] & Individual Experience \\
\hline $\begin{array}{l}\text { Hamsafar Bash va Bebin [Travel with Me and } \\
\text { See] }\end{array}$ & Cultural Realism \\
\hline Safar-e Cheshmeh'ha [Travel of Rivers] & Educational Fiction \\
\hline $\begin{array}{l}\text { Safarname'ye } \quad \text { Kotouleh } \quad \text { [Kotouleh } \\
\text { Travelogue] }\end{array}$ & Cultural Realism \\
\hline $\begin{array}{l}\text { Panj Rouz dar Nimrouz [Five Days in Half a } \\
\text { Day] }\end{array}$ & Cultural Realism \\
\hline Darya'ye Gomshode [The Missing Sea] & Cultural Realism \\
\hline $\begin{array}{l}\text { Ka'beh dar Ghalb-e Kouchakam [Kaaba in my } \\
\text { Little Heart] }\end{array}$ & Religious Realism \\
\hline $\begin{array}{l}\text { Zir-e Navdan-e Tala [Under the Golden } \\
\text { Rainwater Pipe] }\end{array}$ & Religious Realism \\
\hline Adolescents Stories & Theme and Genre \\
\hline $\begin{array}{l}\text { Bazgasht be Zamin pas az Zohour [Return to } \\
\text { the Earth after the Manifestation] }\end{array}$ & Religious Science Fiction \\
\hline $\begin{array}{l}\text { Houshmandan-e Sayareye Urak [Geniuses of } \\
\text { the Urak Planet] }\end{array}$ & Entertainment, Science Fiction \\
\hline $\begin{array}{l}\text { Bazmandegane Sayareye Mairox [Survivors of } \\
\text { Mirox Planet] }\end{array}$ & Political Science Fiction \\
\hline Mosafer-e Sayareye Urapus [The Passenger & Entertainment, Science Fiction \\
\hline
\end{tabular}


Raz-e Ghal'eye Aflak [The Secret of the Aflak Cultural Fiction Castle].

\begin{tabular}{|c|c|}
\hline Sari'tar az Nour [Faster than the Light] & Ethical Science Fiction \\
\hline $\begin{array}{l}\text { Mantaghe'ye Sefr-e Fazaei [Zero Space } \\
\text { Region] }\end{array}$ & Social Science Fiction \\
\hline $\begin{array}{l}\text { Safar be Sarzamin Eshgh [Travel to the Love } \\
\text { Land] }\end{array}$ & Religious Realism \\
\hline $\begin{array}{l}\text { Gozideye Safarnameye Naser Khosrow be } \\
\text { Zabane Emrouz [A Selection of Travelogue of } \\
\text { Naser Khosrow in Modern Language] }\end{array}$ & Historical Realism \\
\hline $\begin{array}{l}\text { Mosafere Gheble [The Passenger of Qibla] } \\
\text { Safarnameye Naser Khosrow Ghobadiani } \\
\text { [Travoluge of Naser Khosrow Ghobadiani] }\end{array}$ & Historical Realism \\
\hline $\begin{array}{l}\text { Kamtar az Khasi dar Miqat [Less than a Twig } \\
\text { in Miqat] }\end{array}$ & Religious Realism \\
\hline
\end{tabular}

\section{Conclusion}

Many travel writing are written for children and adolescents in Iran. This suggests that such literature has audiences. Since children are mentally getting grown at the last years of primary school, they become more interested in literature. Thus, they need to be acquainted with the cultures and customs of different countries and cities through books related to social science and also Travels writing. There is different from in level of children's understanding and their mental characteristics for relating to travel writing. The quality of writing Travels writing for children has been improving since 2000. And many travels writing have been released. In case writers scrutinize the children literature more precisely and professionally, such works will be greatly developed from both quality and quantity viewpoints.

\section{References}

Amouzadeh Khalili, F. (1989). Safar be Shahre Soleiman (Travel to the Solomon's City). Tehran: Amir Kabir Publications.

Amouzgar, H. (2012). Safarnameye Naser Khosrow be Zabane Emrouz [Travelogue of Naser Khosrow in Modern Language] Tehran: Ganjineye Adabiate Kohan Publications.

Arabzadeh, H. (2004). Hamsafar Bash va Bebin [Travel with Me and See]. Tehran: Ghalam Publications.

Azimi, Z. (2003) Majmou'e Dastan'haye Elmi Takhayoli [Science-Fiction Stories] Babolsar: Rojin Publications.

Bashiri, F. (2007). Safarhaye Dara VA Sarah dar Iran[Travels of Dara and Sarah across Iran-Orumieh], Tehran: Kanune parvareshe fekrie kudakan VA nojavanan.

Chatrnour, H. (1983). Aghaz-e Safar [The beginning of Travel]. Tehran: Gheseye Jahan Nama Publications.

----------(1983). Az Ghatar ta Kashti [From Train to the Ship]. Tehran: Gheseye Jahan Nama Publications.

(1983). Shahr'e Badkonak'ha [The City of Balloons] Tehran: Javaneh Publications.

Ebrahim, N. (1977). Safarhaye duro deraze hami VA kami dar vatan [the long journey of Hami and Kami across the country], Tehran: Sorush publication.

Esmaeili, F. (1988). Safar-e Daryaei [Traveling by Sea]. Tehran: Chakavak Publications.

Ghayour Kazemi, F. (2009). Xva Y Bazmandegane Sayareye Mairox [X \& Y, the Survivors of Mirox Planet]. Mashhad: Sokhan Gostar Publications.

Ghezelayagh, Soraya (2006).Adabiate kudak VA nojavan VA tarvije khandane[children and adolescents' literature and cultivating reading culture], Tehran: Samt.

Grogan, H. (2008). Kamtar az Khasi dar Miqat [Less than a Twig in Miqat], a Travelogue of Hajj-e-Tamattu 2008. Tehran: Institute for the Intellectual Development of Children and Young Adults.

Haddad Adel, G. (2009). Social science book of the third grade of primary school, Tehran; Amuzesh VA parvareshi. Hasanbeigi, E. (2001). Ka'beh dar Ghalb-e Kouchakam [Kaaba in my Little Heart]. Tehran: Sepid Publications.

Hejazi, B. (2004).Children and adolescents characteristics and aspects' literature [vizhegiha va janbeha adabiyate kudak]Tehran: Roshangaran VA Motaleate zanan.

Hemati, H. (1990). Safar-e Saltanati be Behesht [Royal Travel to Heaven]. Tehran: Koushiran Kou Publications.

Hoseinein, M. (2010). Sari'tar az Nour [Faster than the Light] Tehran: Institute for the Intellectual Development of Children and Young Adults 
Jalali, M. (2015)." Female Writers and the Millennial Myths of Shāhnāmeh in Iranian Children's Literature 19902000", Education Journal. Special Issue:Gender, Peace and Education. Vol. 4, No. 1-1, pp. 1-5. doi: 10.11648/j.edu.s.2015040101.11.

Kalhor, F. (1996). Houshmandan-e Sayareye Urak [Geniuses of the Urak Planet]. Tehran: Ghadyani Publications

Kamari, A. (2011). Mosafere Gheble [The Passenger of Qibla] Tehran: Institute for the Intellectual Development of Children and Young Adults.

Karachi, R. (2002).Didarhaye dur-adabiate safarnameye[far visits], Tehran: Chapar.

Katouli, H. (1991). Safar-e Cheshmeh'ha [Travel of Rivers]. Tehran: Astane Ghods Publications.

Khansari, A. (1990). Se Hamsafar [Three Traveling Companions]. Tehran: Hamkelsai Publications.

Najafi, A. (2001). Mosafer-e Sayareye Urapus [The Passenger of Urapus Planet]. Tehran: Zekr Publications.

Navaei Lavasani, H. (2009) Raz-e Ghal'eye Aflak [The Secret of the Aflak Castle]. Tehran: Soore Mehr Publications

----------- (2009). Mantaghe'ye Sefr-e Fazaei [Zero Space Region] Tehran: Institute for the Intellectual Development of Children and Young Adults

Nik Talab, R. (2005). Safarhaye Dara VA Sarah dar Iran[Travels of Sarah and Dara across Iran Kerman]. Tehran: Kanune farvareshe fekrie kudakan VA nojavanan, Vol 2.

Mazbanani, M. (1997). Panj Rouz dar Nimrouz [Five Days in Half a Day]. Tehran: Institute for the Intellectual Development of Children and Young Adults.

-----------(1992).Darya'ye Gomshode [The Missing Sea]. Tehran: Institute for the Intellectual Development of Children and Young Adults.

Mazinani, M. (1990).panj ruz dar nimruz[ five days in mid- day], Tehran: Kanune parvareshe fekrie kudakan VA nojavanan.

Mohajer, N.A.(2007). Zir-e navdane tala[under the golden downpipe]. Tehran: Kanune farvareshe fekrie kudakan VA nojavanan.

Mohammadi, M., Hadi Vaghabeni, Z. (2001). Tarikhe adabiate kudak Iran[the history of children literature of Iran], Tehran, Chista, v 6.

Panahi, A. (2009) "Manifestations of the culture of the Iranian people to travel", Monthly history and geography, No. 133, June, S50-45.

Pour Esmaeili, H. (1990). Safar'haye Atal O Matal [Travels of Atal \& Matal]. Tehran: Sherkate Khas Publications.

Rahimi Bandar Abadi, E. (2002) Bazgasht be Zamin pas az Zohour [Return to the Earth after the Manifestation] Ghom: As'har Publications

Roberts, A. (2000), Science Fiction, London: Routledge.

Safi, Gh.. (2003).Aeen negaresh VA virayesh[the principles of writing and editing], Tehran: Arasbaran.

Seyed Arab, Z. (1991). Safar-e Barf [Tavel of Snow]. Tehran: Soroush Publications.

Shajareh, B. (2008). Safarhaye Dara VA Sarah dar Iran[Travels of Dara and Sarah across Iran-Isfahan], Tehran: Kanune parvareshe fekrie kudakan VA nojavanan, Vol6.

----------- (2008). Safarhaye Dara VA Sarah dar Iran-Travels of Dara and Sarah across Iran[Ghom and Kashan], Tehran: Kanune parvareshe fekrie kudakan VA nojavanan, Vol7.

Zemanati Yar, M. (2003). Safar be Sarzamin Eshgh [Travel to the Love Land]. Tehran: Institute for the Intellectual Development of Children and Young Adults.

Yamini Sh. (1956). Donyagardie jamshido Mahshid [Jamshid and Mahshid traveling all around the world]. Tehran: Sepehr ,Amir Kabir publisher. 